\title{
内頸動脈鼓室内露出症例
}

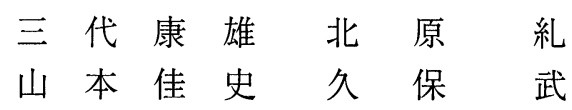

要旨 : 慢性穿孔性中耳炎を伴う内頸動脈鼓室内露出症例について報告する。症例は 58 歳女性で，右難聴 と耳鳴を主訴に当科を紹介受診した。右鼓膜は大穿孔を認め, 鼓室前方に拍動する腫瘤を認めた。内頸 動脈鼓室内露出が疑われ, 平成 13 年 3 月局所麻酔下に耳後部切開の鼓室形成術 I 型を行った。術前に内 頸動脈の露出が確認されていたため, この部位は軟骨板で被覆するのみとし, 殆ど出血無く手術を終了 した。内頸動脈鼓室内露出はきわめて珍しいが, 手術操作などによる大出血で気付いたという症例が大 半であり，鼓室内に拍動性腫瘤を認めた場合は内頸動脈の露出も鑑別に入れるべきである。

キーワード : 内頸動脈, 鼓室内露出, 慢性穿孔性中耳炎

\section{Summary Aberrant Internal Carotid Artery in the Middle Ear:}

Yasuo Mishiro, Tadashi Kitahara, Yoshifumi Yamamoto, and Takeshi Kubo. Department of Otolaryngology, Osaka University School of Medicine

An aerrant internal carotid artery (ICA) with chronic otitis media is reported in this paper. The patient was a 58-year-old female. A pulsatile mass was seen through the perforation of the tympanic membrane, and CT scan showed a defect of the lateral bone of ICA. Type I tympanoplasty was performed and the aberrant ICA was covered with auricular cartilage. Here we discuss the clinical presentation, radiographic investigations and management of this patient.

Key words : aberrant internal carotid artery, chronic otitis media

はじめに

内頸動脈の走行異常による鼓室内露出は高位頸 静脈球やアブミ骨動脈遺残といった他の血管異常 に比べて, 頻度は少ない。また文献的に報告され た症例 ${ }^{1-4)}$ の多くは, 手術などの操作による大量 出血で内頸動脈の露出を疑うという経過である。

今回, 慢性穿孔性中耳炎に伴う内頸動脈の鼓室 内露出症例で, 術前より内頸動脈の露出を診断し ていたため，大量出血をきたすことなく手術を施 行しえた症例を経験したので, 若干の文献的考察 を加えて報告する。
症例

症例 : 58 歳, 女性

主訴 : 右難聴・耳鳴

既往歴 : 特記すべきものなし

家族歴 : 特記すべきものなし

現病歴: 約 20 年前より右耳漏を繰り返し, 右 拍動性耳鳴を感じていたが, 放置していた。平成 12 年 11 月頃より, ジーという耳鳴が加わるよう になり，近医耳鼻咽喉科を受診した。右慢性穿孔 性中耳炎の診断で平成 13 年 1 月 17 日当科に紹介 され受診した。

聴力 : 3 分法聴力レベルで左は $26.7 \mathrm{~dB}$, 右は $55.0 \mathrm{~dB}$ であった（図 1)。 


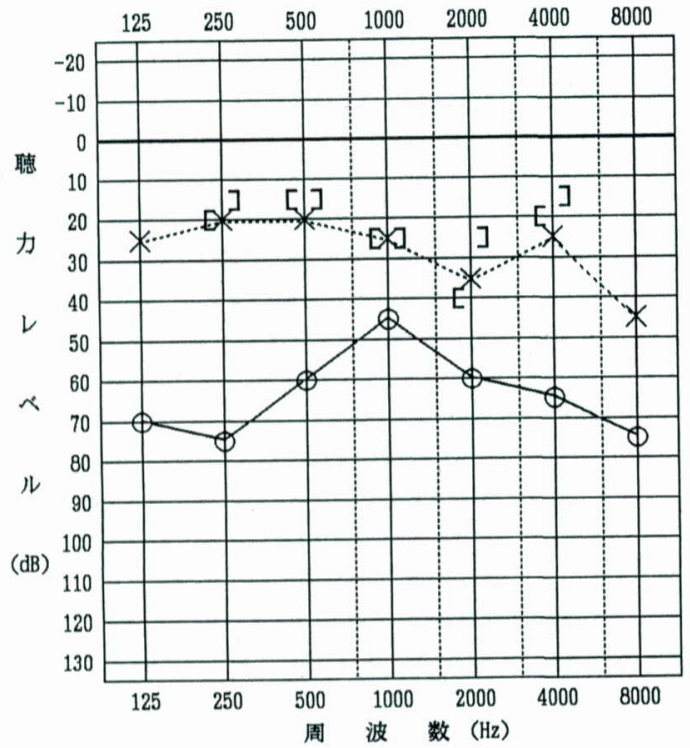

図 1 術前オージオグラム

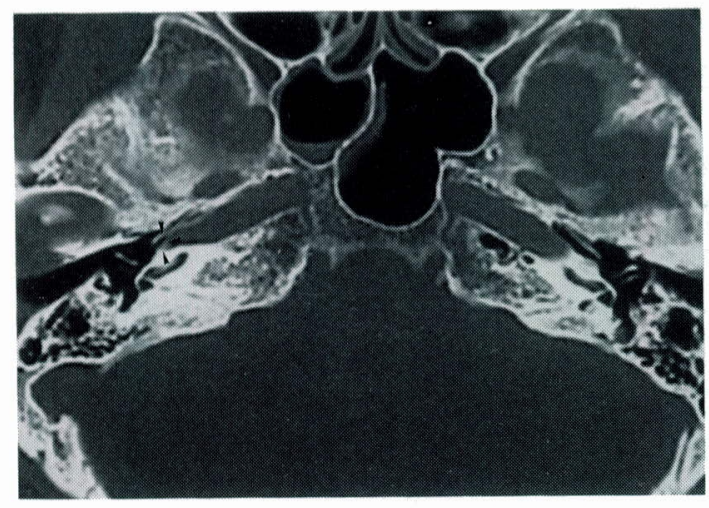

図 3 CT 所見

右内頸動脈外側の欠損（矢頭）を認めた。

鼓膜所見：右鼓膜には中心性大穿孔があり，鼓 室岬角前方に拍動する赤色の腫瘤を認めた（図 2)。

CT 所見：右中耳の含気は良好であったが, 内 頸動脈外側の骨欠損を認めた（図 3 ）。

以上より，右慢性穿孔性中耳炎を伴う内頸動脈 鼓室内露出の診断で平成 13 年 3 月 7 日局所麻酔 下に右鼓室形成術を施行した。

手術所見：耳後部切開でアプローチし, 通常の 鼓室形成術 I 型を施行した。赤色の腫瘤はやはり 内頸動脈であった（図 4)。露出する内頸動脈は耳 小骨との接触はなかったが, 耳介軟骨板で被覆し た。出血はごく少量であった。

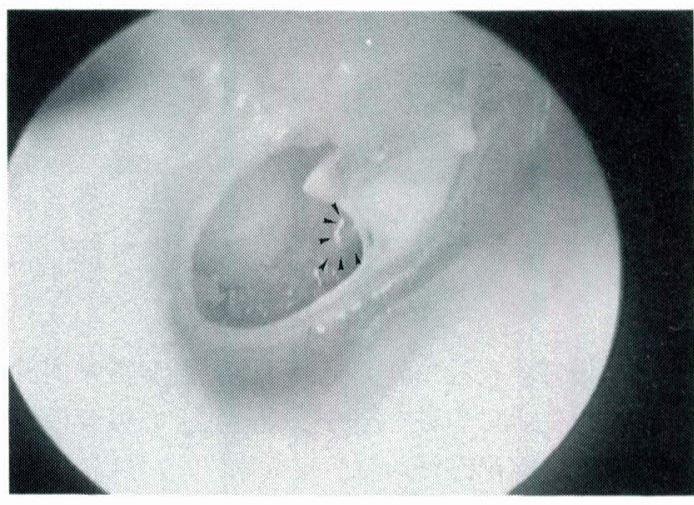

図 2 術前鼓膜写真

大穿孔の内側に拍動する腫瘤（矢頭で囲んだ部分） を認めた。

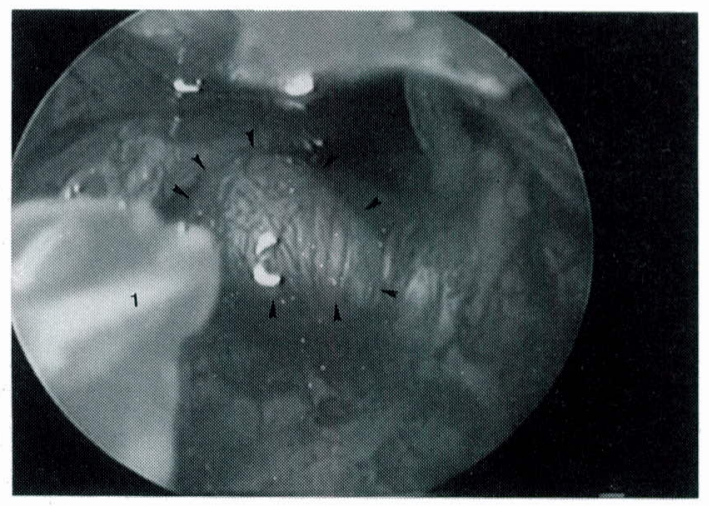

図 4 術中内視鏡写真

矢頭で囲んだ部分に露出する内頸動脈を認めた (1はツチ骨柄)。

術後, ジーという耳鳴は変わらないが, 拍動性 耳鳴は半分以下に減少し, 術後 2 年後の聴力は $31.7 \mathrm{~dB}$ に改善した（図 5)。

\section{考察}

内頸動脈の走行異常による鼓室内露出はきわめ て稀である。Myerson ${ }^{5)} ら は 200$ 例の側頭骨剖検 で 2 例に頸動脈管の骨に 6 個の小さな骨欠損を認 めたとしているが, 完全な骨欠損例は認めていな い。また筆頭著者は 2500 例以上の中耳手術の経 験を有するが, 内頸動脈の鼓室内露出は初めての 経験であった。内頸動脈垂直部の外側の骨の厚さ は $0.5 \mathrm{~mm}$ とされている ${ }^{6)}$ 。本症例の場合, 中耳 炎による骨欠損なのか先天性の走行異常かの鑑別 が問題であるが, 真珠腫ではなく CT でも軟部組 


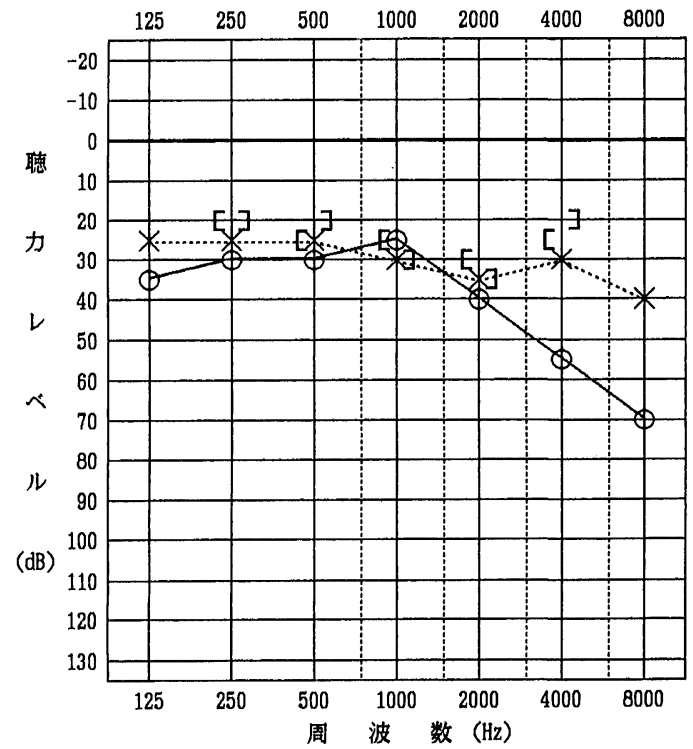

図 5 術後 2 年目のオージオグラム

織陰影のない軽度の炎症であること, 露出した内 頸動脈が岬角の骨より外側に突出しているのを術 中に確認したことより，中耳炎による骨欠損とい うより軽度の内頸動脈の走行異常と考えられた。

児玉ら ${ }^{1)}$ は自験例を含む 37 例の内頸動脈走行 異常症例について報告している。自覚症状として は聴力低下 22 例, 耳鳴 16 例（うち拍動性耳鳴 11 例), めまい 5 例などであり, 鼓膜所見は正常鼓 膜だが中〜下鼓室に腫瘤透見 23 例（拍動性腫瘤 6 例), 滲出性中耳炎様所見 7 例, 鼓膜膨隆 5 例な どであった。初期診断としてはグロームス腫瘍が 14 例と最も多く, 滲出性中耳炎 8 例, 血管腫 4 例 などである。また鼓膜切開や手術による異常出血 で, 初めて内頸動脈の走行異常を疑った例が 25 例 $(68 \%)$ ，検查のみで診断のついた例が 12 例 (32\%) であったとしている。

画像診断では CT（特に造影 CT）が最も有用で あるという意見 ${ }^{2,6-8)}$ が大多数である。脳血管造 影は有用であるが, 合併症の危険性を考えると必 須の検查ではない7)。本症例でも鼓膜穿孔より内 頸動脈の露出が確認できていたため, 脳血管造影 は施行していない。MRAは脳血管造影に比べて 安全であるが，骨がうつらないため，CTよりも 有用性は劣る ${ }^{6)}$ 。

中耳の血管性病変を疑う場合の鑑別診断として
は内頸動脈走行異常の他にグロームス腫瘍, 高位 頸静脈球，コレステリン肉芽腫, 内頸動脈瘤など があげられる。内頸動脈走行異常は鼓膜のやや前 方に, 高位頸静脈球やグロームス腫瘍はそれより やや後方に透見されるとされるが，これらの鑑別 にもCT が最も有用とされている6,7)。 Remley ${ }^{7)}$ らは自覚的耳鳴もしくは拍動性鼓膜病変を持つ患 者にはすべてまず最初の画像検查として側頭骨高 分解 CTを施行すべきだと述べている。

治療に関しては Ruggles ら ${ }^{8)}$ は露出した内頸動 脈を筋膜で被覆してから，外耳道後壁骨を採取し， これで内側へ押し达むという手術法を報告してい る。しかしながらこの方法は内頸動脈の狭窄を起 こす可能性があり，危険であるという批判もあ $3^{6)}$ 。それ以外には露出した内頸動脈と耳小骨の 接触による拍動性耳鳴の軽減のために, ツチ骨柄 を切断したり ${ }^{3)}$ ，シリコン板を間に挿入した報 告9) がある。ただし内頸動脈走行異常が判明した 時点で, 極力手術は避けるべきという意見が大多 数である。本症例では鼓膜穿孔があり, 穿孔を放 置すると外傷などで大出血の危険性があるために， 鼓室形成術を施行した。内頸動脈露出部には保護 の目的で大きめの耳介軟骨板を留置したが,

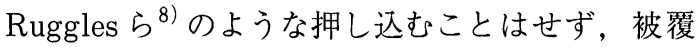
したのみである。患者には鼓膜切開は絶対に受け ない, 右耳に関しては当院と紹介医でのみ診察を 受けるように指導している。

本症例は鼓膜穿孔があり, 術前より内頸動脈走 行異常による鼓室内露出が確認されていたため, 安全に手術を施行できた。しかしながら鼓室内拍 動性病変を認めた場合には内頸動脈走行異常も念 頭に入れ検査を進め, 安易な生検や手術は慎むべ きであることを再認識した。

\section{まとめ}

1）慢性穿孔性中耳炎に伴う内頸動脈鼓室内露 出症例を報告した。

2）鼓室内拍動性病変を認めた場合, 内頸動脈 走行異常も念頭に入れ, 安易な生検や手術は慎む ベきである。

本論文の要旨は第 14 回日本頭頸部外科学会にてロ演 (ビデオ) した。 


\section{参考文献}

1）児玉 章, 河西研一, 木村元俊, 他 : 内頸動脈の異 常走行を伴った慢性中耳炎症例. 耳鼾臨床, $83: 41$ 47, 1990.

2) McEleveen JTJr, William WML, Tarek HE et al: Aberrant internal carotid artery : Classic findings on computed tomography. Otolarungol Head Neck Surg 94:616-621, 1986.

3) Glasscock ME, Dickins JRE, Jackson CG et al: Vascular anomalies of the middle ear. Laryngoscope $90: 77-88,1980$.

4) Glasgold AI, Horrigan WD: The internal carotid artery presenting as middle ear tumor. Laryngoscope $82: 2217-2221,1972$.

5) Myerson MC, Rubin H, Gilbert JG: Anatomic studies of the petrous portion of the temporal bone. Arch Otolaryngol 20 : 195210, 1934.

6) Botma M, Kell RA, Bhattacharya $J$ et al : Aberrant internal carotid artery in the middle-ear space. J Laryngol Otol 114 : 784787, 2000.

7) Remley KB, Coit WE, Harnsberger HR, et al: Pulsatile tinnitus and the vascular tympanic membrane: CT, MR, and angiographic findings. Radiology 174 : 383389, 1990.

8) Ruggles RL, Reed RC: Treatment of aberrant carotid arteries in the middle ear: A report of two cases. Laryngoscope 82 : 11991205, 1972.

9) Sinnreich AI, Parisier SC, Cohen NL et al: Arterial malformation of the middle ear. Otolaryngol Head Neck Surg 92:194-206, 1984. 